\title{
The Kids are Alright: Middle-Level Students' Perceptions of School during COVID-19
}

\section{Anne Gutshall: Department of Teacher Education College of Charleston, Charleston, USA.}

Joshua D. McCall: College of Charleston, Charleston, USA.

\begin{abstract}
This research sought to determine middle school students' perceptions of the academic year they experienced during the COVID-19 pandemic in a district in South Carolina. The students were surveyed three times throughout the year (beginning, midyear, and end of year), and their responses were disaggregated by the instructional model choice (face-to-face, in-person instruction, and online, virtual instruction via webcam technology). Families of students in this district were offered a choice of these two instructional models throughout the year, and the reasons for their family's choice were surveyed. Students who were face-to-face for the entire year were more likely to perceive their school year as a positive experience than their online peers, but both groups identified that despite the circumstances, they mostly felt positive about the year, except in the case of being able to make friends, in which face-to-face students' responses were significantly more positive. Also, students reported spending time during the previous school year's shutdown (March 2020 to the end of the school year in June) completing many different academics and social tasks in which they were able to develop skills and direct their free time. The results of this research suggest that consistent with previous research suggesting that offering a few options results in people feeling satisfied, this research suggests that in the future, when faced with difficult choices at the district level on how to handle student experiences in unprecedented circumstances, offering choice to the students and families may benefit the outcomes of those students and the district overall.
\end{abstract}

Key words: COVID-19, Middle school students, School choice, Face-to-face Instruction, Online instruction.

\section{Introduction}

Across the United States, during the COVID-19 pandemic, it was little more than a guessing game when it came to predicting how to proceed with the 2020-2021 school year following unprecedented nationwide school closures in the spring of 2020. Kuhfeld et al. (2020) projected that student academic performance would be negatively impacted from the beginning of the school year based on previous findings examining pre-COVID-19 student absenteeism, summer learning loss, and school closures due to weather. Kuhfeld et al. (2020) assumptions were accurate compared to the baseline data analyzed by Curriculum Associates (2020). Findings suggested that students began the school year at higher rates of below grade-level proficiency in most instances (e.g., disaggregated for race, subject area, and median household income) than in the prior few years. Many states responded to this unprecedented challenge with innovative instructional models and buyins to various online educational tools (Reimers \& Schleicher, 2020).

Likewise, concerns regarding student mental health and wellness were expressed in the guidance issued by the American Academy of Pediatrics. They noted that "Schools and school-supported programs are fundamental to child and adolescent development and well-being and provide our children and adolescents

International Journal of Educational
Studies
Volume 4, Issue 3, pp. 117-126
2021
DOI: 10.53935/2641-533x.v4i3.163
a Corresponding Author: Joshua D. McCall
Funding: This study received no specific
financial support.
Article History:
Received: 1 October 2021
Revised: 29 October 2021
Accepted: 19 November 2021
Published: 9 December 2021
C 2021 by the authors; licensee Academic
Publishing Group
117 
with academic instruction, either in-person or virtually; social and emotional skills; safety; reliable nutrition; physical/occupational/speech therapy; mental health services; health services; and opportunities for physical activity, among other benefits." Similar concerns were expressed by the American Psychological Association (APA). Of top concern were documented increases in childhood and adolescent depression, suicidal ideation, and eating disorders presumably due to social isolation, stress, and difficulty accessing needed mental health interventions due to COVID-19 restrictions. In November 2020, according to Rebecka Leeb, lead for the CDC COVID-19 response team, “... from March through October, the proportion of mental health-related emergency department visits increased $24 \%$ for children aged 5 to 11 , and $31 \%$ among teenagers aged 12 to 17 years, compared to 2019." Nationwide, pediatricians and mental health providers expressed worries about children and adolescent mental health concerns, especially those who had related vulnerabilities before the lockdowns and social isolation.

Across the United States, educators wondered how children and adolescents would fare when school started back up for the 2020-2021 school year after the sudden worldwide shut down due to the pandemic. Across the country, there were student enrollment declines for public schools alongside upticks in enrollment for private, charter and home school options, especially when the public school options were online only (Butcher \& Burke, 2021). However, educational response varied tremendously across the country, with differences in opening dates and in-person versus online learning opportunities varying significantly from state to state and school district to school district. Data collected by Burbio (2021) tracked the openings of US school districts throughout the year, and at the end of the year, it is estimated that $78 \%$ of states (39) had at least $80 \%$ of their most populated districts offering a five-day week schedule to their families. This was not the case for the entire year, as many states and districts slowly modified their plans to meet the needs of their families, their students, and the evolving (Center for Disease Control, 2021)protocols. Researchers found that less than twenty states $(>40 \%)$ offered an entirely traditional instructional model at the beginning of the year. Younger students (Kindergarten-5th grade) were more likely than their middle (6th-8th grade) and high school (9th-12th grade) peers to be in school, with middle school just slightly more likely to be in school than high school students.

In South Carolina (SC), mask ordinances were less stringent, and COVID-19 restrictions were more lenient than in California, New York, and Washington (Burbio, 2021). SC was among the first states to offer in-person learning options as early as September 2020. Governor Henry McMaster (South Carolina) strongly encouraged districts across the state to offer a five-day-a-week, in-person learning model for families and students who wanted it. Much later, after vaccines became widely available, he signed into law S.704, requiring that starting April 26th, 2021, all districts in South Carolina must have an in-person option available to families. In connection with this law, SC State Superintendent of Education Molly Spearman said, "Every family must be given the option of sending their child to school five days a week, face-to-face, and the science shows that this can be done safely in every community" (Bustos, 2021). In South Carolina, Governor McMaster strongly encouraged school districts to provide both in- person and online learning options for families to choose what best worked for them.

The present study took place in Bravo School District (BSD), a large school district outside of a major city in South Carolina. This district served 35,218 students in the 2020-2021 school year. Following state legislation, masks were required to be worn on school buses as they were South Carolina Department of Education property and only encouraged once a student entered a school building. Despite many districts in the state choosing to continue distance learning well into the 2020-2021 school year, BSD offered choice to their families from the start of the 2020-2021 school year. Prior to the start of the school year, the district identified students needing remediation due to low engagement in the spring of 2020 distance learning, low performance on benchmark testing in 2020, and other determining factors. The students had the opportunity to attend LEAP (Learn, Evaluate, Analyze, Prepare) days in person at the beginning of the year with certified teachers to help close some of their academic gaps and prepare them for the 2020-2021 school year. Parents and students could select the learning pathway that best fit their needs, choosing from a traditional five-day in-person instruction option with masks and social distancing, an online learning option that took place with the student's teachers and peers in their home school, or an entirely virtual instruction option for grades 7-12 through a third party. Although the virtual option was available to seventh and eighth graders, the course selections were limited, and because of that, middle school students who hypothetically would have chosen

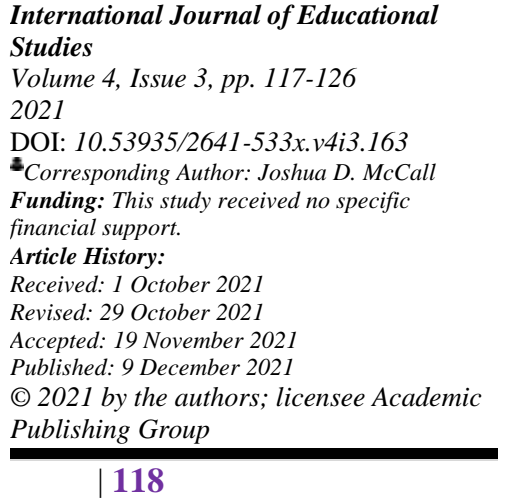


this third party online option would not take the required classes to advance to high school. In reality, the only options available to middle school students were the traditional and online from home pathways.

The traditional in-person instruction pathway that students and families could choose was modeled after a typical school year, that is, a year in which COVID-19 did not exist. Teachers would instruct students with live and engaging lessons inside of the classroom with students in desks attentively learning. There would be social distancing as much as possible, with sanitation of desks and highly touched surfaces between each class. Masks were encouraged to be worn by students and teachers, not required. Students were assigned the same seat for the entirety of the course, and the administration used seating charts to track possible exposure to the COVID-19 virus. During the year, a parent could request their student(s) transition from the traditional pathway to the online (or vice versa) at any time. It was up to district personnel and school building administration to approve or deny their request.

In contrast to the traditional setting, online learning occurred from the student's home via live instruction from the BSD classroom streamed across a Google Meet or ZOOM. Students were voyeurs into the classrooms of five to six teachers each day, often having little to no interaction other than a check-in question or a mundane attendance response of "here." For the most part, students in the traditional or online format completed the same assignments via an online Google Classroom classwork tab. Technical difficulties were common, but most teachers tried to manage the balance of dual-modality teaching to the best of their ability. BSD was one of many districts in South Carolina requiring its teachers to simultaneously instruct in-person students and online students.

Making educational decisions during COVID-19 was a problem for many school leaders across the globe. Solutions for how best to educate students while keeping them safe varied from state to state during this unique time. In the United States, some districts and states offered virtual instruction only while some attempted to offer face to face instruction while following CDC guidelines for mask wearing and social distancing. It will be some time before educational research can sift through the myriad of approaches to determine which polices were the best for students. Understanding which solutions worked best for students, however, is essential for future education planning during unexpected global health crises. This study is a unique portrayal of one middle school and students' perceptions of their experiences.

\subsection{Aims of the Current Research}

This research seeks to explore the attitudes and perceptions of middle school students at Stellar Middle School (SMS) in Bravo School District (BSD) about their school experiences during the COVID-19 pandemic. While educational policy research during COVID-19 is widely available, this research is among the first to explore middle school students' perceptions of school. SMS is located in South Carolina in a school district that offered parents a choice each quarter for instructional modality. They could decide between in-person (face-to-face) schooling and online schooling options beginning September 8th of the 2020-2021 school year, a date slightly delayed from usual, but that included a full 180-day instructional calendar.

\subsection{Research Questions}

1. What are middle school students' perceptions for why they or their parents chose face-to-face versus online schooling during COVID-19?

2. Were students satisfied with their chosen mode for learning?

3. What are middle school students' perceptions regarding their end-of-year learning, friendships and readiness for the next school year by chosen mode of learning?

4. What are middle school students' perceptions about the 2020-2021 school year using just one word?

5. How did middle school students make use of their extended time out of school during the pandemic?

Studies

Volume 4, Issue 3, pp. 117-126

2021

DOI: $10.53935 / 2641-533 x . v 4 i 3.163$

Corresponding Author: Joshua D. McCall Funding: This study received no specific financial support.

Article History:

Received: 1 October 2021

Revised: 29 October 2021

Accepted: 19 Nover 2021

Accepted: 19 November 202

(C) 2021 by the authors; licensee Academic

Publishing Group$$
119
$$

\section{Material and Method}

School team leaders had previously requested to work with the principal investigator as part of a yearlong school-wide professional development (PD) program called BrainBuilders (Gutshall \& Attafi, 2021). BrainBuilders is a school-based intervention that delivers PD to teachers over one academic school year. Teacher beliefs and student beliefs are typically surveyed three times during the project, at the school start (August), after the winter break (January) and at the end of the school year (April). In addition, teachers 
participate in activities designed to impact their understanding of key concepts from mind, brain and education science, including neuroplasticity, how the brain learns, growth mindset, caring for the brain, grit, and self-control. As part of the protocol, students and teachers were administered the initial belief survey in September. However, after the first eight weeks of school, the PD project was abandoned because teachers were overwhelmed with coping with the ever changing COVID-19 impact. Student surveys were still administered in January and April, and at the principal's request, COVID-19 related questions were added to survey questions to gauge students' perceptions of their experiences in school to improve student outcomes and support student well-being during the unusual year. This pivot in the scope of the research provided an opportunity for real time survey questions but was not the original intent of the research.

As stated previously, Stellar Middle School (SMS) students and their families were given a choice about how they would like their student(s) to attend school for the 2020-2021 school year. Students could attend face-to-face in a socially distanced, face-masked setting with heavy use of plexiglass screens or online, where students attended their usual classes via Google Meet from home. Overall, families each quarter could negotiate their school instructional format selection and change due to changes in pandemic status. The instructional format varied for the 844 students at SMS, but only those who voluntarily responded to the survey are included in this research. The range of survey respondents and selected mode of instruction is summarized in the table below:

Table-1. Instructional format modalities for survey respondents

\begin{tabular}{llll}
\hline $\begin{array}{l}\text { Instructional } \\
\text { Format }\end{array}$ & $\begin{array}{l}\text { Beginning of School Year } \\
\text { (September) } \mathbf{n = 6 2 9}\end{array}$ & $\begin{array}{l}\text { Middle of School Year } \\
\text { (January) } \mathbf{n = 5 4 3}\end{array}$ & $\begin{array}{l}\text { End } \\
\text { Year(May) } \mathbf{n = 5 2 4}\end{array}$ \\
\hline Face-to-face & $41.5 \%(261)$ & $57.1 \%(310)$ & $61.3 \%(321)$ \\
Online & $58.5 \%(368)$ & $42.9 \%(233)$ & $38.7 \%(203)$ \\
\hline
\end{tabular}

Surveys were administered to students by their homeroom teacher during a teacher-selected time over a one-week timeframe via an online Google form survey. There were 629 responses to the first survey in September, 543 responses to the midyear survey in January, and 524 responses to the final survey in May. For the most part, only data from the students who were exclusively face-to-face or online for the entire year was used from each survey. From the pool of respondents, 186 students were face-to-face in the school building for the entire year, identified as "face-to-face," and 193 students received their instruction at home for the entire year, identified as "online."

\begin{tabular}{ll} 
Table-2. Instructional format modalities survey responses during the 2020-2021 academic year. \\
\hline Instructional Format & Percentage $(\mathbf{n = 5 2 4})$ \\
\hline Face-to-face & $35.5 \%(186)$ \\
Online & $36.8 \%(193)$ \\
Mixture (changed at some point during the year) & $27.7 \%(145)$ \\
\hline
\end{tabular}

\section{Results}

Question 1: What are middle school students' perceptions for why they or their parents chose face-to-face versus online schooling during COVID-19?

There were two major themes identified from the survey when students were asked the open-response question, "What do you think was the biggest reason(s) you and your family decided to choose face-to-face or online?" The responses were disaggregated based on face-to-face or online students for the entire year, and each group had a majority answer. The face-to-face student's major theme endorsed by $59.1 \%(110)$ of students were educational outcomes. These concerns came from perceptions about struggles from the student's previous online experience in the early weeks of the pandemic, the student not being able to focus on a computer screen for six to seven hours a day, and general understanding that being in front of a teacher was more conducive for learning than being in front of a screen. In contrast, online students' major theme, shared by $75.1 \%$ (145 students), was family health and safety concerns as the number one reason for keeping their child(ren) home to receive their education online this past year. These responses cited living with an elderly family member, having a high-risk immediate family member, or just general concern of the COVID19 virus. Of almost equal importance at around 10\% (12.4 and 11.8 respectively), face-to-face students wrote

International Journal of Educational
Studies
Volume 4, Issue 3, pp. 117-126
2021
DOI: 10.53935/2641-533x.v4i3.163
a Corresponding Author: Joshua D. McCall
Funding: This study received no specific
financial support.
Article History:
Received: 1 October 2021
Revised: 29 October 2021
Accepted: 19 November 2021
Published: 9 December 2021
C 2021 by the authors; licensee Academic
Publishing Group
| 120 
that their family needs (e.g., no supervision at home) and the need for the socialization function of school were the reasons their family chose to send their child to the brick and mortar building to receive their education. Again, around 10\% (10.9 and 9.7 respectively) of online and face-to-face students did not explain the reasoning behind their family's choice but gave an all-encompassing "I like being at home" or "I prefer being at school more." Lastly, the final categories of reasoning at $<10 \%$ were not knowing their parents' reasoning or not listing a reason (online 8.8; face-to-face 4.8), being unwilling to wear masks (online 1.6; face-to-face 0), and being waitlisted (online 0.5; face-to-face 0). Student responses are summarized in Table 2 .

Table-3. Student Perceptions of Instructional Mode Decisions.

\begin{tabular}{|c|c|c|}
\hline Reason for Instructional Mode Selection & $\begin{array}{l}\text { Exclusively Face-to- } \\
\text { face }\end{array}$ & $\begin{array}{l}\text { Exclusively } \\
\text { Online }\end{array}$ \\
\hline $\begin{array}{l}\text { Health and Safety Concerns: the student's health; an } \\
\text { elderly or high-risk family member; high-risk } \\
\text { environment }\end{array}$ & $2.2 \%(4)$ & $75.1 \%(145)$ \\
\hline $\begin{array}{l}\text { Educational Concerns: cannot focus at home; was } \\
\text { failing during end of previous year, can ask teacher } \\
\text { questions easily }\end{array}$ & $59.1 \%(110)$ & $3.1 \%(6)$ \\
\hline $\begin{array}{l}\text { Familial Needs: no supervision, tired of having the } \\
\text { student at home, did not have the necessary Wifi } \\
\text { bandwidth }\end{array}$ & $12.4 \%(23)$ & $0 \%(0)$ \\
\hline $\begin{array}{l}\text { Socialization: needed to make friends; was new to the } \\
\text { area; the parent was worried about their social } \\
\text { skills }\end{array}$ & $11.8 \%(22)$ & $0 \%(0)$ \\
\hline $\begin{array}{l}\text { Preference: online/face-to-face without explanation; } \\
\text { (e.g., "I like being in school" or "I preferred working } \\
\text { from home") }\end{array}$ & $9.7 \%(18)$ & $10.9 \%(21)$ \\
\hline $\begin{array}{l}\text { Unsure: the child was unsure; was not told the } \\
\text { parent's reasoning for the choice; no response }\end{array}$ & $4.8 \%(9)$ & $8.8 \%(17)$ \\
\hline Masks: Did not want to wear masks & $0 \%(0)$ & $1.6 \%(3)$ \\
\hline $\begin{array}{l}\text { Waitlisted: The child was waitlisted to become face- } \\
\text { to-face }\end{array}$ & $0 \%(0)$ & $0.5 \%(1)$ \\
\hline
\end{tabular}

Question 2: Were students satisfied with their chosen mode for learning?

Students were asked the following question as part of the final survey given in May 2021, "This year students were able to pick face to face or online schooling. Overall, were you happy with your choice?" For the larger group, the 524 surveyed students who responded to survey 3, 80.3\% of students responded, "yes," indicating they were pleased with their choice for schooling modality this year. When responses were disaggregated by those who chose exclusively face-to-face instruction for the year, the percentage of students happy with their choice rose to $94.1 \%$. However, fewer students, $65.8 \%$, who chose exclusively online instruction indicated they were pleased with their choice.

Question 3: What are middle school students' perceptions regarding their end-of-year learning, friendships and readiness for the next school year by chosen mode of learning?

Students were asked the following question, Given the pandemic and all that has taken place for me in school, I think my learning in school is:

About the same

Studies

Volume 4, Issue 3, pp. 117-126

Volume

DOI: $10.53935 / 2641-533 x . v 4 i 3.163$

Corresponding Author: Joshua D. McCall Funding: This study received no specific

financial support.

Article History:

Received: 1 October 2021

Revised: 29 October 2021

Accepted: 19 Nover 2021

Accepted: 19 November 202

(c) 2021 by the authors; licensee Academic

Publishing Group

Better than usual

Not as good as usual 
Table-4a. Student end-of-year perceptions responses.

\begin{tabular}{llll}
\hline & About the same & Better than usual & Not as good as usual \\
\hline Total $(\mathrm{n}=524)$ & $44.3 \%(232)$ & $19.3 \%(101)$ & $36.5 \%(191)$ \\
Face-to-face $(\mathrm{n}=186)$ & $50.5 \%(94)$ & $18.3 \%(34)$ & $31.2 \%(58)$ \\
Online $(\mathrm{n}=193)$ & $37.3 \%(72)$ & $19.7 \%(38)$ & $43.0 \%(83)$ \\
\hline
\end{tabular}

Students were also asked the following question, How able were you to make friends in a socially distanced year?

I was able to make about the same number of friends

I was able to make more friends this year

I was able to make fewer friends than a usual year

Table-4b. Student end-of-year perceptions response

\begin{tabular}{llll}
\hline & About the same & More friends & Fewer Friends \\
\hline Total $(\mathrm{n}=524)$ & $39.7 \%(208)$ & $14.5 \%(76)$ & $45.8 \%(240)$ \\
Face-to-face $(\mathrm{n}=186)$ & $53.2 \%(99)$ & $21.0 \%(39)$ & $25.8 \%(48)$ \\
Online $(\mathrm{n}=193)$ & $23.8 \%(46)$ & $5.7 \%(11)$ & $70.5 \%(136)$ \\
\hline
\end{tabular}

Students were also asked the following question, When I think about next year in school, I think:

I am ready to move up to the next grade

I am not sure if I am ready for the next grade

I will need help to get ready for the next grade

\begin{tabular}{llll}
\multicolumn{4}{c}{ Table-4c. Student end-of-year perceptions responses } \\
\hline & Feels Prepared & Unsure if Ready Needs Assistance \\
\hline Total $(\mathrm{n}=524)$ & $69.3 \%(363)$ & $20.0 \%(105)$ & $10.7 \%(56)$ \\
Face-to-face $(\mathrm{n}=186)$ & $71.0 \%(132)$ & $18.8 \%(35)$ & $10.2 \%(19)$ \\
Online $(\mathrm{n}=193)$ & $71.5 \%(138)$ & $18.1 \%(35)$ & $10.4 \%(20)$ \\
\hline
\end{tabular}

Overall, $70 \%$ of students, regardless of instructional mode choice, indicated they feel academically prepared for the upcoming school year. Likewise, close to $70 \%$ of student responses indicated that their ability to learn this year was about the same as usual or even better than usual, regardless of instruction mode. Not surprisingly, the groups diverged with regard to student perceptions of their ability to make friends, and $70.5 \%$ of students in the exclusively online mode indicated that they made far fewer friends than in a typical year, compared to $25.6 \%$ of students in the face to face group who indicated they made fewer friends this year.

Question 4: What are middle school students' perceptions about the 2020-2021 school year in one word?

Students were given the following open-ended prompt, " One word that best describes this year in school is." Students provided an array of words that were synonymous with each other, such as "awful," "bad," "terrible," horrible," and "worse," which were compiled into singular categories identifying the most frequent word in its group as "awful." Once the most frequently appearing word categories were established $(n=15$; range $=10-80)$, the connotation of the words was explored via a Google survey to a randomized assortment of higher education faculty, middle school teachers, and middle school students. The survey required these individuals to assign, on a Likert scale, the connotation that they most closely associated with the provided word. The options were mostly negative, somewhat negative, somewhat positive, and mostly positive. From the total pool of respondents, ten surveys from each category were selected at random, and their connotations of the provided words were averaged with $\geq 80 \%$ confidence rating. Each word was assigned a positive, neutral, or negative connotation. If a student responded with more than one word or a word that could not be put into a distinct category of words, they were excluded from the data set. If a student put random letters, symbols, or a made-up word (not including slang), they were also excluded from the data set. Response summaries can be found in Table 5. 
Table-5. Student one-word prompt responses; Associated connotations from the survey.

\begin{tabular}{llc}
\hline Word Connotation & $\begin{array}{l}\text { Exclusively } \\
\text { Face-to-face (n=186) }\end{array}$ & $\begin{array}{c}\text { Exclusively } \\
\text { Online ( n=193) }\end{array}$ \\
\hline $\begin{array}{l}\text { Words with a negative connotation: isolated, stress, } \\
\text { frustrating, chaotic, awful, difficult, and boring }\end{array}$ & $45.7 \%(85)$ & $62.7 \%(121)$ \\
$\begin{array}{l}\text { Words with a neutral connotation: changes, unexpected, } 11.3 \%(21) \\
\text { odd, and different }\end{array}$ & $8.8 \%(17)$ \\
$\begin{array}{l}\text { Words with a positive connotation: interesting, } \\
\text { awesome, fun, and good }\end{array}$ & 25.3\% (47) \\
$\begin{array}{l}\text { Responses excluded because they were infrequent, left 17.7\% (33) } \\
\text { blank, or were multiple words: IDK, masks, } \\
\text { and fun and sad [together] }\end{array}$ & $11.9 \%(23)$ \\
\hline
\end{tabular}

Overall, students in both instructional modalities were more likely to associate the school year with words that had negative connotations. Online students had a higher percentage of negative connotation words $(62.7 \%)$ of total respondents compared to their traditional peers $(45.7 \%)$. These words included but were not limited to "isolated," "stress," "frustrating," "chaotic," "awful," "difficult," "boring," or many other synonymous words. Students, regardless of instructional modality, were least likely to provide words with neutral connotations such as "changes," "unexpected," "odd," or "different." Conversely, face-to-face students were more likely $(25.3 \%)$ to provide words that had a positive connotation to describe their school year than their online peers $(16.6 \%)$. The responses were similar among the groups and included words such as "interesting," "awesome," "fun," "good," or other synonymous words. Unfortunately, with an open-ended prompt, students were able to write whatever they chose, and some chose to fill in the blank with gibberish, not write anything at all, or just put "IDK." Those responses from both the online and face-to-face students have not been counted in the data because they could not be put into a connotative category.

Question 5: How did middle school students make use of their extended time out of school during the pandemic?

Students were asked the following question: "During the year when school was disrupted, you might have spent more time on other things and even grown new skills. Tell what activity or skill you spent time on." Students responded $(\mathrm{n}=449)$ with the various ways in which they spent their time during the COVID-19 disruption. Analysis of the entire group of student responses regardless of instructional format choice revealed eight major categories noted in Table 6.

Table-6. Student use of extra time responses.

\begin{tabular}{ll}
\hline Categories & Participants (n=449) \\
\hline $\begin{array}{l}\text { Physical Activity: organized sports, dance, working out, } \\
\text { running, swimming, walking, fishing }\end{array}$ & $25.4 \%(114)$ \\
$\begin{array}{l}\text { Academic tasks: reading for pleasure, learning a foreign } \\
\text { language, working on math, computer programming, writing poetry and stories }\end{array}$ & $20.7 \%(93)$ \\
$\begin{array}{l}\text { Artistic tasks: painting, drawing, origami, coloring, } \\
\text { crocheting }\end{array}$ & $12.7 \%(57)$ \\
$\begin{array}{l}\text { Virtual Games: video games, cosplay, anime } \\
\text { Musical Activities: practicing the ukulele, writing songs, } \\
\text { guitar, piano }\end{array}$ & $12.5 \%(56)$ \\
$\begin{array}{l}\text { Self-improvement: practicing patience, minding my business, focusing more, } 4.9 \%(22) \\
\text { talking to more people, getting to know and } \\
\text { grow more about myself }\end{array}$ & $5.8 \%(26)$ \\
$\begin{array}{l}\text { Socialization: spending time with friends and family } \\
\text { No response: I don't know, not sure, or no response }\end{array}$ & $4.2 \%(19)$ \\
\hline
\end{tabular}

Overall, students reported spending time on a variety of healthy and wholesome activities. As shown in the table above, overwhelmingly, students described the multitude of ways they kept occupied when they were out of school. Of note was the number of students who persisted with tasks largely considered academic, 
including working on math, learning a foreign language, and reading. Specific examples of student responses included the following:

"Got to talk to ALOT of my old friends and we've become a little group and I learned Korean" "Gaming, bowling, learning and playing piano, hanging out with friends and a little better social skills" "Skateboarding, I decided to get back into that hobby"

"Drawing and collecting glass bottles and jars, I also looked for worms to feed the chickens" "Babysitting, reading cooking, baking, cleaning, organizing”

"Playing basketball outside"

"Going outside running, exercising and reading" "Drawing and trampoline tricks"

"I tried out speedcubing (Rubik's cube) because it looked fun and interesting" "Math"

"I spent time on reading and writing my book"

The wording of the prompt and the request to share what skills students had grown during the out-ofschool time undoubtedly contributed to the positive nature of the student responses. However, the responses provided by this group of more than 500 students suggest that time out of school was not necessarily time away from learning and growth in a variety of essential developmental areas.

\section{Discussion}

Students at one middle school in South Carolina during a global pandemic responded to 3 anonymous surveys about their experiences in school during the 2020-2021 school year during the global COVID-19 pandemic. Three themes emerged from the data, including family choice, online vs. face-to-face differences, and non-academic student growth. First, globally, responses from students were positive regarding the ability to choose either online or face-to-face instruction. As educators learn lessons from the pandemic, it may be beneficial to adopt the BSD school district's model, which focuses on family choice. Consistent with models regarding choice, satisfaction, and autonomy (Reutskaja \& Hogarth, 2009), it is probable that when families are given options for their child rather than being told their mode for instruction, satisfaction, and general well-being are more positive. This finding is consistent with previous research on school choice in the United States suggesting that parents who utilize school choice options are more satisfied with their students' experiences in school than those who do not DeAngelis (2004), Schwartz (2004) and Chernov and Goodman (2015), it is possible that not only giving families a choice, but just 3 choices, added to student satisfaction levels. Schwartz suggests that humans like choices, but not too many, which can result in feeling less satisfied due to overwhelming options. In this case, families could choose face to face instruction, online instruction with their peers and teachers, or fully virtual instruction with a third party provider. It is possible that limited choice added to satisfaction.

Secondly, while most students were pleased with their instruction mode choice, students in the exclusively online group were more likely than face-to-face students to report dissatisfaction with their choice. In addition, another finding gleaned from the student responses suggested an overarching theme that students who chose online models of instruction were more likely to describe the experience using a word with a negative connotation than were their peers who chose face-to-face instruction for the year. Related, exclusively online students also reported less ability to make friends during the academic year than their peers who attended school exclusively face-to-face, confirming the concerns about social isolation and impact put forth by various professional groups such as the American Psychological Association (APA) and the American Academy of Pediatrics (AAP). Taken together, student responses suggest that face-to-face instruction is preferable, more positive, and more socially facilitative than exclusively online instruction for most middle school students.

A third and final finding in the data relates to students' rich responses when asked how they spent their time outside of school to grow new skills and talents. While child advocates and educational professionals universally have expressed concerns regarding probable declines in academic performance and possibly social and emotional wellness, more than 500 responses from one South Carolina Middle school suggest that students spent time independently growing and developing life skills, specifically referencing activities like working on their academic skills, learning new languages, playing sports outside and honing their musical instruments. Consider the work of Barker et al. (2014), which noted that less structured time in the lives of elementary-age children resulted in increased executive function skills presumed to be a positive consequence of choosing how to direct one's leisure and self without the constant adult direction found in more structured 
settings. This finding is a reminder that learning how to use free time and develop recreational and leisure skills constructively could be an unintended positive outcome for students as a result of the forced isolation of the pandemic.

\section{Conclusion}

There will undoubtedly be many years of research and data collection forthcoming to understand the impacts of forced online education and social isolation resulting from the COVID-19 pandemic. As policy makers worldwide examine the impacts of policy decisions on families, students and school enrollments (Butcher \& Burke, 2021), nuanced understandings of student perceptions of their experiences during this novel time are emerging slowly. Moreover, educational leaders may want to consider, not just offering choice, but also offering limited choice to families in order to increase satisfaction with their child's education. Schwartz (2004); Chernov and Goodman (2015). Results detailed in this research suggest that face-to-face schooling is preferable to online schooling for many reasons and support the CDC's recent recommendations for all students in the United States to return to in- person school experiences for the upcoming 2021-2022 year (CDC). While limited to one middle school in a state where students and families could opt into face-to-face schooling as early as September 2020, student responses suggest that students are resilient, and many family environments supported students' growth in interpersonal and leisure skills beyond the classroom setting. In the future, research designed to explore family choice, number of choices, and possibly no choice options with regard to satisfaction and experiences in educational decisions during unprecedented and unexpected times may prove informative to guide educational leadership decisions.

\section{References}

Barker, J. E., Semenov, A. D., Michaelson, L., Provan, L. S., Snyder, H. R., \& Munakata, Y. (2014). Less- structured time in children's daily lives predicts self-directed executive functioning. Frontiers in Psychology, 5, 593.

Burbio. (2021). Reference is an internet website. Retrieved from: https://info.burbio.com/school-tracker-trends/.

Bustos, J. (2021). All SC schools to open in person, 5 days a week, with Gov. McMaster's signature. The State. Retrieved from: https://www.thestate.com/news/politics-government/article250836904.html.

Butcher, J., \& Burke, L. (2021). The education lesson from Covid-19: School choice is imperative for every child Backgrounder \#3582: Heritage Foundation.

Center for Disease Control. (2021). Guidance for COVID-19 prevention in school. CDC. Retrieved from: https://www.cdc.gov/coronavirus/2019-ncov/community/schools-childcare/k-12-guidance.html.

Chernov, A., \& Goodman, J. (2015). Choice overload: A conceptual review and meta-analysis. Journal of Consumer Psychology, 25(2), 222-358.

Curriculum Associates. (2020). Understanding student needs: Early results from fall assessments, research brief. Retrieved from: https://www.curriculumassociates.com/-/media/mainsite/files/i-ready/iready-diagnostic-results-understanding-student-needspaper-2020.pdf.

DeAngelis, C. (2004). School sector and satisfaction: Evidence from a nationally representative sample. Ed Working Paper ednAnnenberg Institute at Brown University. 19-147.

Gutshall, C. A., \& Attafi, H. (2021). Under Review Brainbuilders: Strengthening teachers' neuroscience and noncognitive knowledge to build elementary students' mindset, self-efficacy, and grit. Trends in Neuroscience and Education.

Kuhfeld, M., Soland, J., Tarasawa, B., Johnson, A., Ruzek, E., \& Liu, J. (2020). Projecting the potential impact of COVID-19 school closures on academic achievement. Educational Researcher, 49(8), 549-565.

Reimers, F., \& Schleicher, A. (2020). Schooling disrupted, schooling rethought. How the COVID-19 pandemic is changing education. $O E C D$.

Reutskaja, E., \& Hogarth, R. M. (2009). Satisfaction in choice as a function of the number of alternatives: When "goods satiate. Psychology and Marketing, 26(3), 197-203.

Schwartz, B. (2004). The paradox of choice. New York: Harper Perrenial.

International Journal of Educational Studies

Volume 4, Issue 3, pp. 117-126

Volume

DOI: $10.53935 / 2641-533 x . v 4 i 3.163$

Corresponding Author: Joshua D. McCall Funding: This study received no specific financial support.

Article History:

Received: 1 October 2021

Revised: 29 October 202

Accepted: 19 November 2021

Accepted: 19 November 202

(c) 2021 by the authors; licensee Academic

Publishing Group 


\section{Appendix}

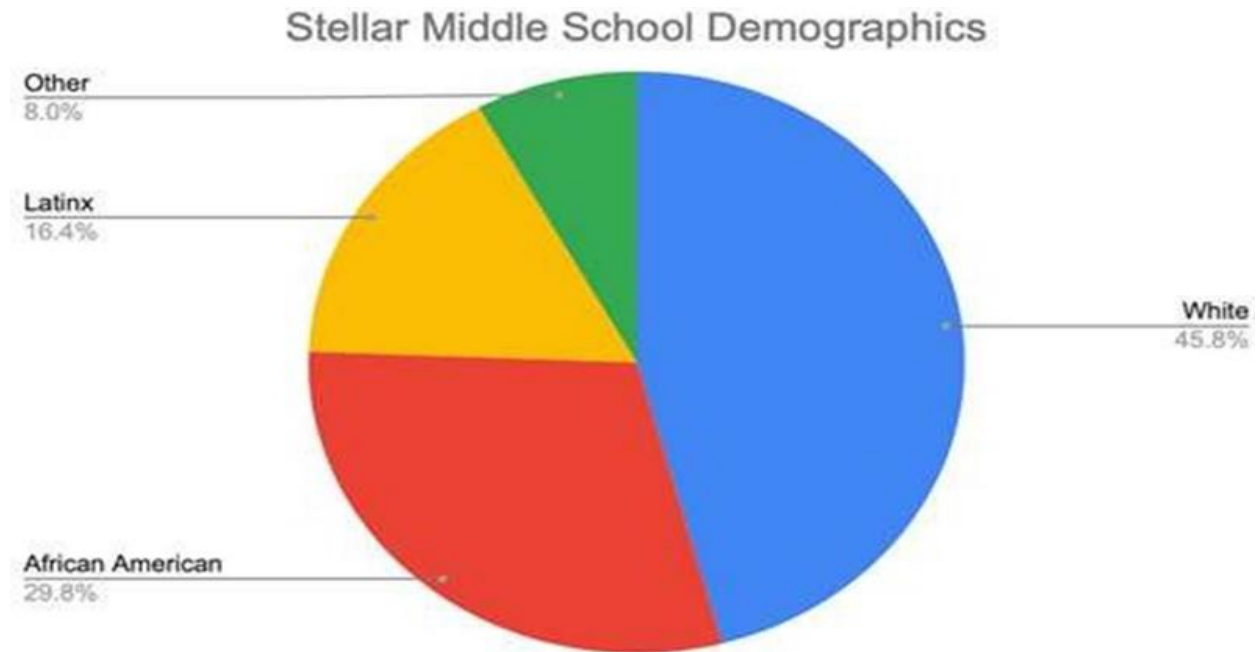

Figure-1. School demographics.
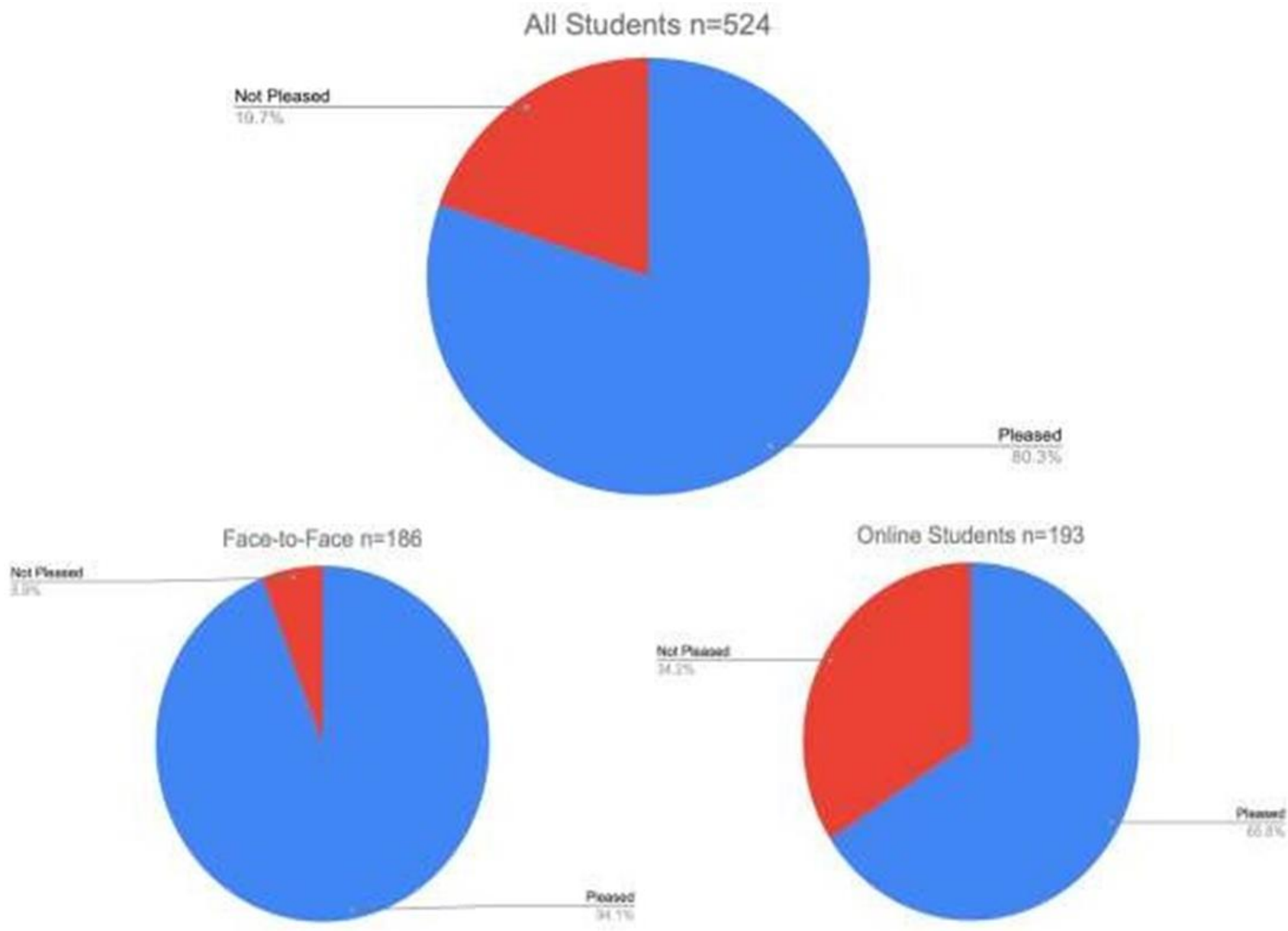

Figure-2. Student satisfaction responses.

Studie

Volume 4, Issue 3, pp. 117-126

2021

DOI: $10.53935 / 2641-533 x . v 4 i 3.163$

Corresponding Author: Joshua D. McCall

Funding: This study received no specific

financial support.

Received: 1 October 2021

Revised: 29 October 202

Accepted: 19 November 2021

Accepted: 19 November 2021

(C) 2021 by the authors; licensee Academic

Publishing Group 